\title{
New excavations at Tel Erani: the Early Bronze Age I fortification walls and early urbanisation in the Southern Levant
}

\author{
Ianir Milevski ${ }^{1,}{ }^{*}$, Marcin Czarnowicz $^{2}$, Dmitry Yegorov ${ }^{1}$, Jacek Karmowski ${ }^{2}$ (D), \\ Marcin Gamrat ${ }^{2}$, Eli Cohen-Sasson ${ }^{3} \&$ Yuval Yekutieli $^{3}$ \\ ${ }^{1}$ Israel Antiquities Authority, Jerusalem, Israel \\ ${ }^{2}$ Institute of Archaeology, Jagiellonian University in Krakow, Poland \\ ${ }^{3}$ Ben-Gurion University of the Negev, Beer-Sheva, Israel \\ * Author for correspondence $\sqrt{ }$ ianir@israntique.org.il
}

Fortification walls and other buildings discovered during renewed excavations at Tel Erani (Tell esh-Sheikh el-Areyni) shed new light on the beginnings of urbanisation in the Southern Levant during the second half of the fourth millennium BC.

Keywords: Southern Levant, Early Bronze Age, fortification walls, urbanisation

\section{Introduction}

Most research regarding the early urbanisation of the Southern Levant has focused on the construction of defensive walls and public buildings. Tel Erani (Tel esh-Sheikh el-Areyni) is located on the border between the Mediterranean coastal plain and the Judean foothills, in present-day Israel (Figure 1). Excavations began there in the 1960s under the first director of the Department of Antiquities (Yeivin 1977) and have continued since, with the most recent fieldwork undertaken in 2019. These expeditions include archaeologists from Tel Aviv University, Ben-Gurion University of the Negev (BGU), the Jagiellonian University in Krakow (JUK) and the Israel Antiquities Authority (IAA) (Kempinski \& Gilead 1991; Ciałowicz et al. 2015), with the support of a team from the University of Buenos Aires.

The tell comprises three main areas: the acropolis in the north, the upper terrace and the lower terrace (Figure 2). Occupying approximately 25ha, the site includes Early (thirty-fifth to thirty-first century BC) and Late Bronze (fourteenth century BC) Age, and Iron Age phases (twelfth to eighth century $\mathrm{BC}$ ), with some remains from the Byzantine (fourth to eighth century $\mathrm{AD}$ ) and Ottoman (sixteenth to twentieth century $\mathrm{AD}$ ) periods.

Yeivin's (1977) excavations in Area $\mathrm{N}$-one of several areas he excavated (Figure 2) revealed the remains of defensive mud-brick walls in the north-western part of the lower terrace. These were re-excavated by a BGU/JUK team (Cialowicz et al. 2015). A salvage excavation during 2015-2016 (Milevski et al. 2016) revealed a new portion of the site's fortification walls. Both complexes in areas N and P-Q date to the Early Bronze (EB) IB1 


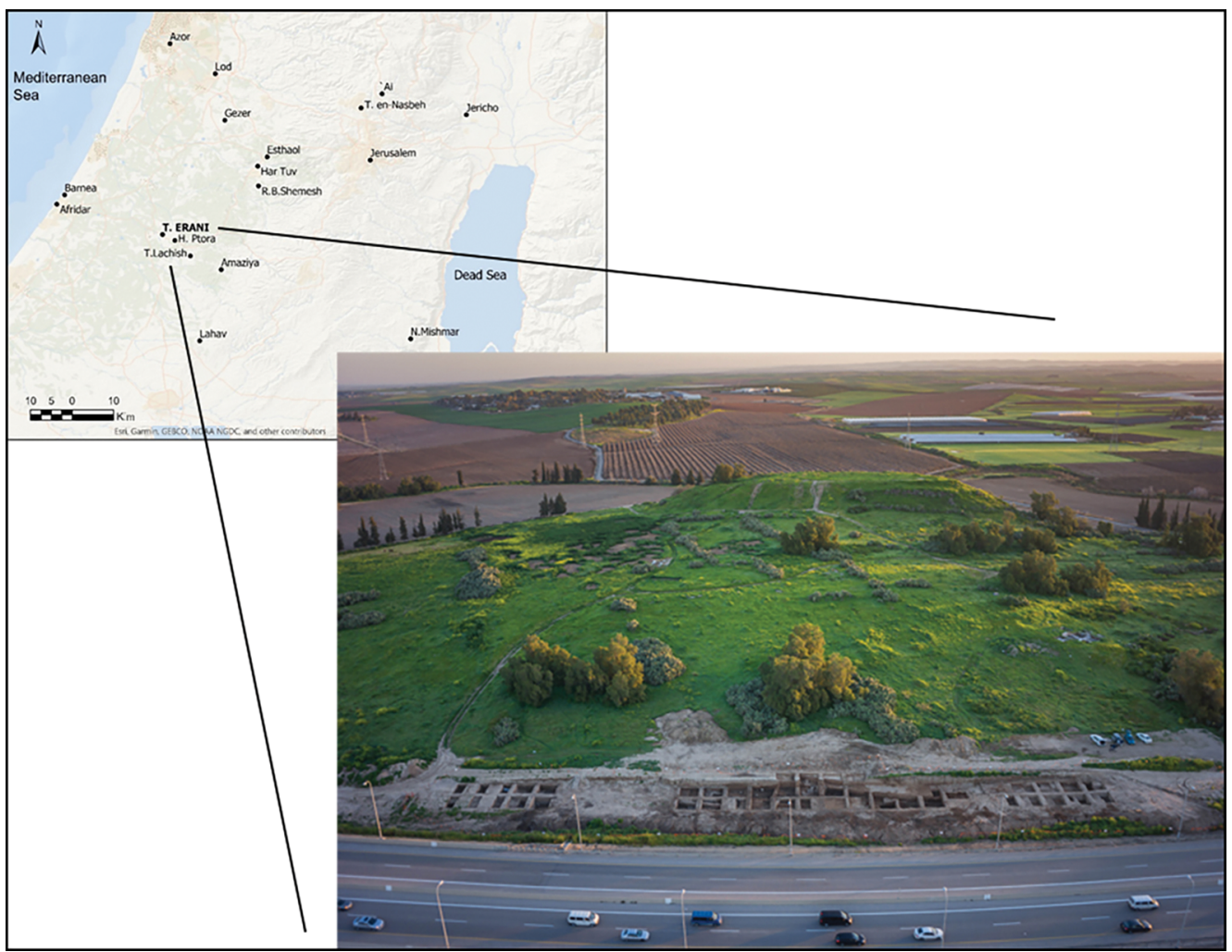

Figure 1. Location map with sites mentioned in the text (inset) (produced by A. Fadida, based on ArcGIS, Esri), with general view of Tel Erani, looking north (2015-2016 season) (courtesy of the Israel Antiquities Authority).

(c. 3300-3100 BC), referred to as the 'Erani C horizon' (Yekutieli 2006) following the nomenclature of the excavation conducted by Kempinski and Gilead (1991).

Building complexes found in Area D, excavated by Yeivin (1977) and later Kempinski and Gilead (1991) (Figure 3), provide some evidence for public buildings or proto palaces. These complexes were also dated to the EB IB1 based on associated pottery.

\section{The defensive walls and the buildings in Area P-Q}

The excavations in 2015-2016 revealed two defensive walls built one on top of the other; these are numbered W200 and W204 (Figures 4 \& 5:1). Excavations reveal several phases of the site that pre-date the fortifications, all of which belonged to the Erani $\mathrm{C}$ horizon.

In 2018-2019, a collaborative excavation between the BGU, JUK and the IAA, along with the team from Buenos Aires University, investigated the inner part of the town in Area P-Q, within the defensive walls (Figure 5:2). Several buildings were found near or attached to the defensive walls. Two main levels were found: one early, probably attached to the inner face of the defensive walls, and with several phases; and one late, which seems to post-date the collapse of the walls. The early level belongs to the Erani C horizon-probably its late phase, according to the associated pottery (Figure 6) and a radiocarbon date from

(C) The Author(s), 2021. Published by Cambridge University Press on behalf of Antiquity Publications Ltd. 
one of the floors (4491 27 BP; GrM-22786: 3348-3092 BC at 95.4\%; date modelled in OxCal v4.2, using the IntCal13 calibration curve; Bronk Ramsey 2009; Reimer et al. 2013).

Immediately below wall W200 was a destruction layer containing floors with in situ pottery vessels belonging to the Erani $\mathrm{C}$ horizon. The pottery was the same type as that found in floors of the structures inside the town (in Area P-Q) that are attached to the fortification walls.

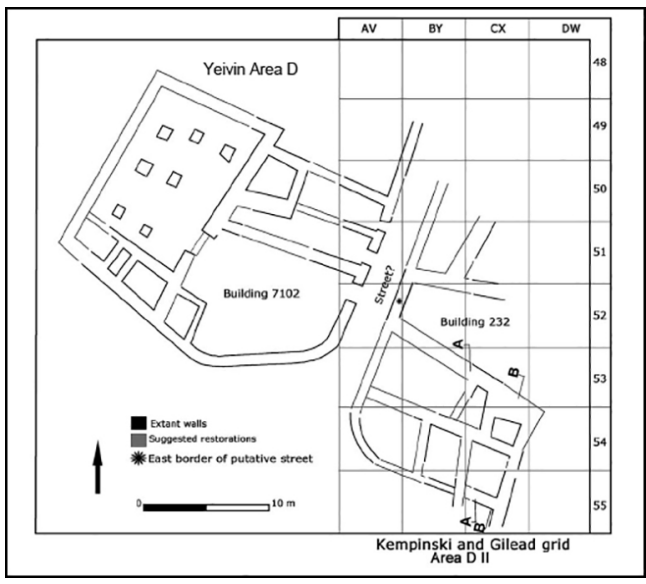

Figure 3. Public building(s) in Area D (adapted from Kempinski \& Gilead 1991; Czarnowicz \& Braun 2019).
A magnetometry survey conducted in 2019 on the edge of the lower terrace, close to areas $\mathrm{N}$ and $\mathrm{P}-\mathrm{Q}$, suggests that other structures existed on the northwestern and southern border of the lower terrace. These are most evident in the south-east of the terrace, where the wall appears to turn northwards following the topography of the lower terrace (Figure 2).

\section{Discussion}

The excavations at Tel Erani have revealed a walled town of the early phase of the EB IB on the Mediterranean coastal plain. The town was probably connected via inter-regional exchange between the coast and the highlands of the Southern

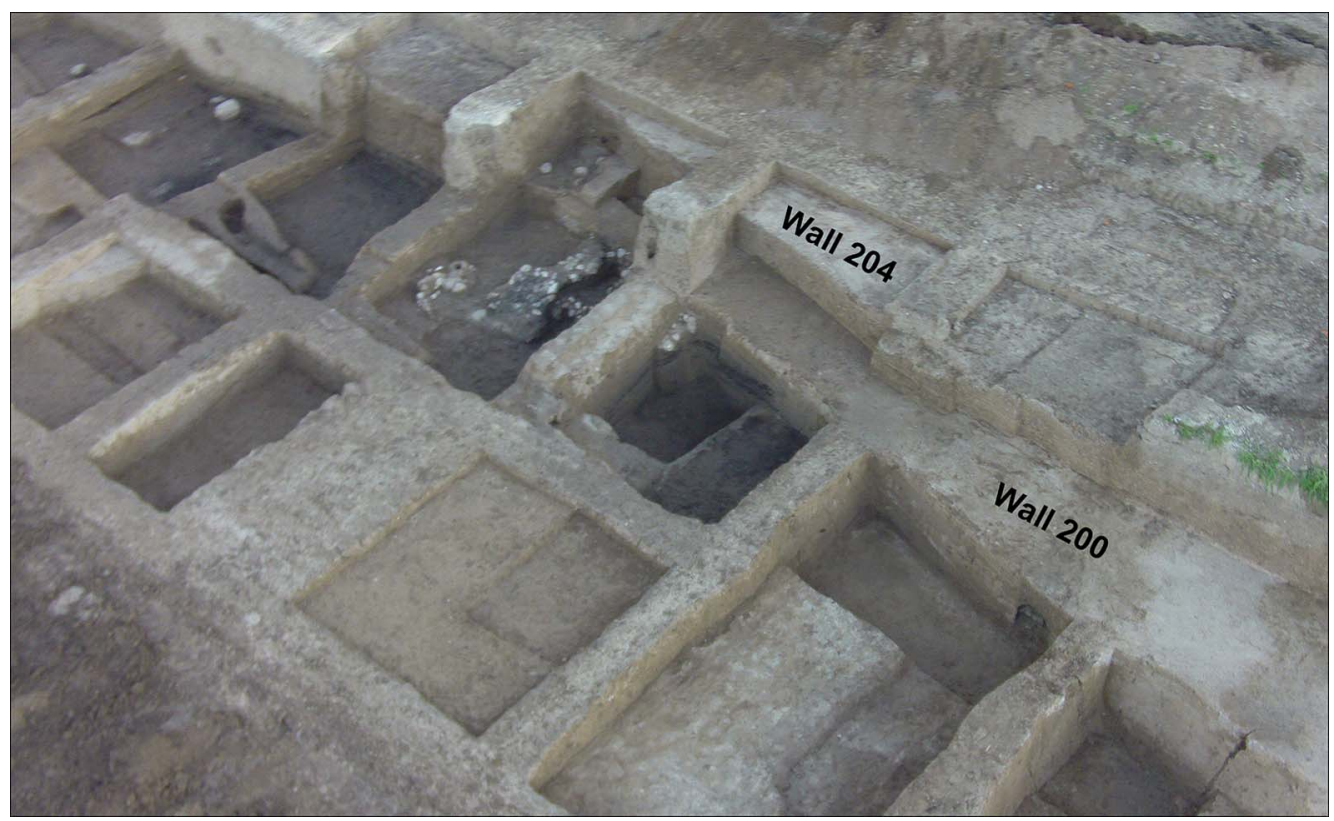

Figure 4. Fortification walls in Area P-Q (2015-2016 season; courtesy of the Israel Antiquities Authority).

(C) The Author(s), 2021. Published by Cambridge University Press on behalf of Antiquity Publications Ltd. 
Levant (Yekutieli 2006; Milevski 2011). The gradually increasing occupation density and the presence of public buildings and defensive town walls suggest an early period of urbanisation and fortification in the central-southern part of the Southern Levant. This surely reflects a type of social organisation led by elite groups (see Shalev 2018).

Tel Erani clearly has some features associated with urbanism: public architecture, evidence for

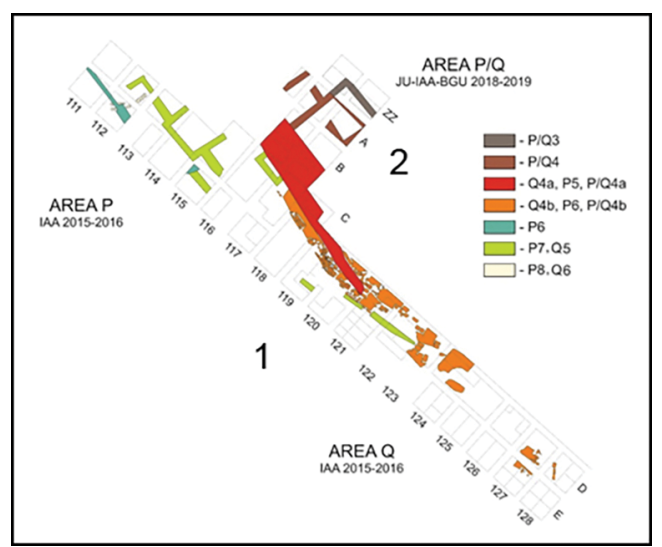

Figure 5. 1) Area P-Q, view offortification walls (20152016); 2) inner buildings attached to the walls (2019). $J U=$ Jagiellonian University; $B G U=$ Ben-Gurion University; $I A A=$ Israel Antiquities Authority (plan drawn by E. Aladjem and $M$. Czarnowicz). economic specialisation and trade, and dense occupation. Other criteria, such as population density, however, cannot be asserted. Early sites in the Southern Levant have some, but not all, of the attributes associated with urbanism (see Childe 1950; Gaydarska 2016; Smith 2016; Woolf 2020). Tel Erani appears to be at a relatively early stage of the urbanisation process in the Near East.

This process can perhaps also be observed at Tel Afek, north of Tel Aviv, at 'Ai, near Jerusalem, and also in the north, at Ein Zippori, Tel Bet Yerah and Tel Shalem (Callaway 1980; Eisenberg 1996; Kochavi et al. 2000; Getzov 2006; Milevski et al. 2014). The material culture-predominantly Erani C horizon

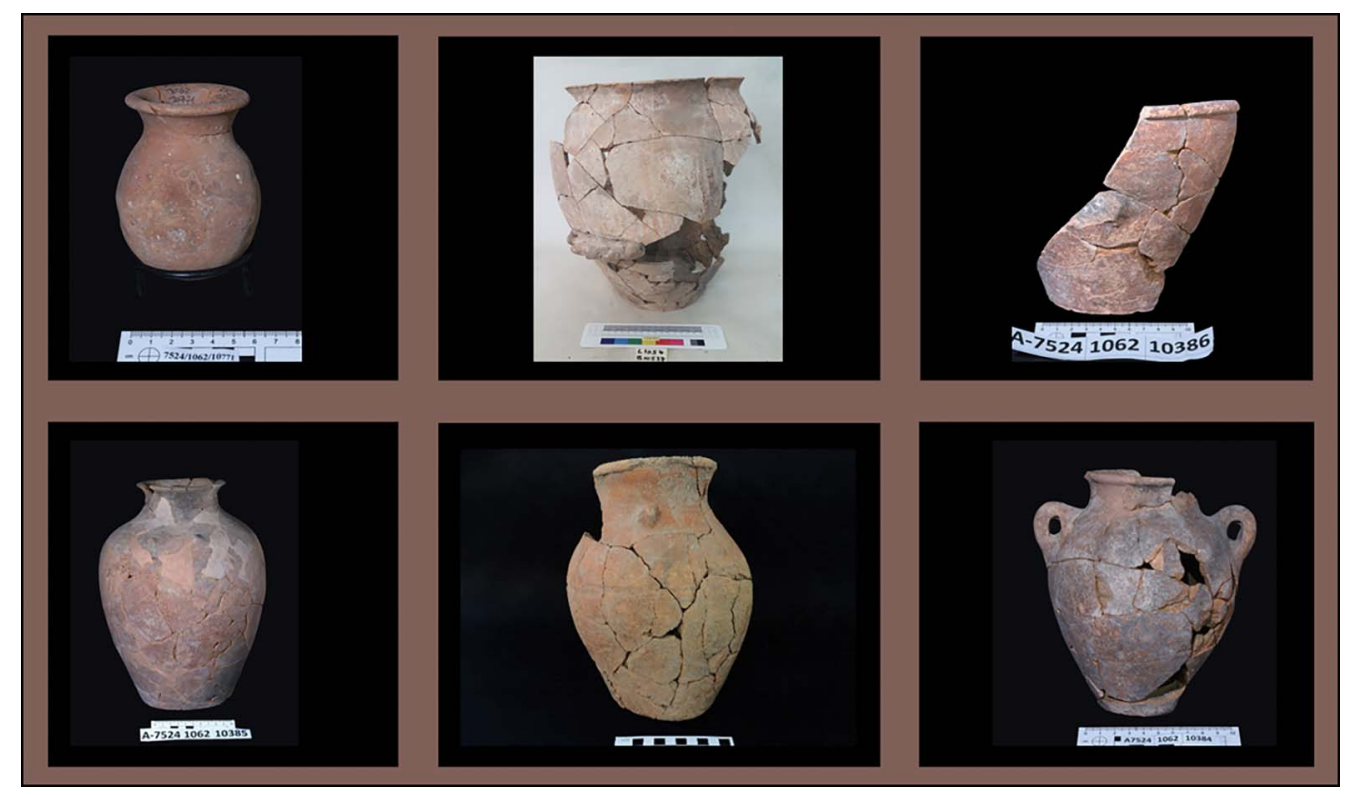

Figure 6. Pottery from the Erani C horizon found in Area P-Q (photographs by C. Amit, courtesy of the Israel Antiquities Authority).

(C) The Author(s), 2021. Published by Cambridge University Press on behalf of Antiquity Publications Ltd. 
pottery-demonstrates how Tel Erani was widely connected, with links to other sites on the coastal plain (e.g. Azor, Lod, Afridar, Barnea); the foothills (e.g. Tel Gezer Hartuv, Eshtaol, Ramat Bet Shemesh, Horbat Ptora, Tel Lachish, Amazyia); the central hill country (e.g. Tel en-Nasbeh, Jerusalem); the Jordan Valley (e.g. Jericho); the Judean desert (e.g. Nahal Mishmar Cave); and the northern Negev (e.g. Lahav) (Yekutieli 2006; Milevski 2011). This pottery is also evident in Lower and Middle Egypt (Czarnowicz 2014) and represents one of the first phases of Levantine interaction with the Nile during the mid-fourth millennium BC.

The following phase of Tel Erani, EB IB2, probably reflects the presence of Egyptians at the site, as evidenced by a ubiquitous presence of Egyptian finds (Czarnowicz et al. 2014). The connection between phase EB IB2 and the earlier Erani C horizon remains unclear, as does the relationship between the Egyptian influence and the earlier fortification walls; this is an area of future research at the site.

\section{Acknowledgements}

The authors wish to thank field supervisors E. Aladjem, M. Pasternak and S. Atkins, along with other members of the field team: J. Regev, E. Boaretto and F. Höflmayer (radiocarbon dating), and M. Kahan, Y. Shmidov, V. Assman and A. Fadida (plans and sections). Thanks are due to students from JUK and UBA, as well as to workers and volunteers from Qiryat Gat, Ashkelon, Kfeife and Abu Kaf. Special thanks also to D. Varga and V. Lipshitz from IAA for their help during all stages of the work.

\section{Funding statement}

This fieldwork and research were funded as part of the salvage excavation by the National Roads Company of Israel, the Israel Scientific Fund, the National Science Centre in Poland and the Fund for Science and Technology (Argentina).

\section{References}

Bronk Ramsey, C. 2009. Bayesian analysis of radiocarbon dates. Radiocarbon 51: 337-60. https://doi.org/10.1017/S0033822200033865

Callaway, J.A. 1980. The Early Bronze Age citadel and lower city at Ai (et-Tell). Cambridge (MA): Harvard University Press.

Childe, V.G. 1950. The urban revolution. Town Planning Review 21: 3-17. https://doi.org/10.3828/tpr.21.1. k853061t614q42qh

CiaŁowicz, K. et al. 2015. Egyptian-Levantine connections: new evidence for Early Bronze Age fortifications and some preliminary results of an initial season of investigation at Tel Erani, Israel. Current Research in Egyptology 15: 13-28. https://doi.org/10.2307/j.ctvh1ds9d.8

Czarnowicz, M. 2014. Erani C pottery in Egypt, in A. Maczyńska (ed.) The Nile Delta as a centre of cultural interactions between Upper Egypt and the
Southern Levant in the $4^{\text {th }}$ millennium BC (Studies in African Archaeology 13): 95-104. Poznan: Poznan Archaeological Museum.

Czarnowicz, M. \& E. Braun. 2019. Observations on the stratigraphic attribution of the Early Bronze Age pillared building in Area D at Tel 'Erani, Israel. Bulletin of the American Schools of Oriental Research 382: 17-32. https://doi.org/10.1086/706070

Czarnowicz, M., M. Pasternak, A. Ochat-Czarnowicz \& J. SŁucki. 2014. The Egyptian presence at Tel Erani, in M. Jucha, J. Dębowska-Luwin \& P. Kołodziejcyk (ed.) Aegyptus est imago caeli: studies presented to K.M. Cialowicz in his $60^{\text {th }}$ birthday: 235-44. Krakow: Jagiellonian University in Krakow.

EISENBERG, E. 1996. Tel Shalem: soundings in a fortified site of the Early Bronze Age IB. 'Atiqot 30: 1-24. 
GaYdarsKa, B. 2016. The city is dead! Long live the city! Norwegian Archaeological Review 49: 40-57. https://doi.org/10.1080/00293652.2016.1164749

Getzov, N. 2006. The Tel Beth Yerah excavations 1994-1995 (IAA Reports 28). Jerusalem: Israel Antiquities Authority.

KempinsKi, A. \& I. GiLEAd. 1991. New excavations at Tel Erani: a preliminary report of the 19851988 seasons. Tel Aviv 18: 164-91. https://doi.org/10.1179/tav.1991.1991.2.164

Kochavi, M., P. Beck \& E. Yadin. 2000. Aphek-Antipatris I. Excavations of Areas A and B: the 1972-1976 seasons. Tel Aviv: Tel Aviv University. https://doi.org/10.1179/tav.1976.1976.1.1

Milevski, I. 2011. Early Bronze Age local exchange in the Southern Levant: a Marxist perspective.

London: Equinox.

Milevski, I., R. Liran \& N. Getzov. 2014. The Early Bronze Age town of Ein Zippori in the Galilee (Israel). Antiquity Project Gallery 88. Milevski, I., D. Yegorov, M.D. Pasternak \& E. Aladjem. 2016. Salvage excavation at Tel Erani, areas $\mathrm{P}$ to U, in K. Cialowicz, Y. Yekutieli \& M. Czarnowicz (ed.) Tel Erani I: preliminary report of the 2013-2015 excavations: 45-58. Krakow: Widawnictwo Alter.
Reimer, P.J. et al. 2013. IntCal13 and Marine13 radiocarbon age calibration curves $0-50000$ years cal BP. Radiocarbon 55: 1869-87. https://doi.org/10.2458/azu_js_rc.55.16947

Shalev, O. 2018. The fortification wall of Tel Erani: a labour perspective. Tel Aviv 45: 193-215. https://doi.org/10.1080/03344355.2018. 1494784

Smith, M.E. 2016. How can archaeologists identify early cities? Definitions, types, and attributes, in M. Fernández-Götz \& D. Krausse (ed.) Eurasia at the dawn of history: urbanization and social change: 153-68. Cambridge: Cambridge University Press. https://doi.org/10.1017/9781316550328.010

Woolf, G. 2020. The life and death of ancient cities: a natural history. New York: Oxford University Press.

Yervin, S. 1977. El-'Areini, Tell esh-Sheikh Ahmed (Tel 'Erani), in M. Avi-Yonah \& E. Stern (ed.) Encyclopedia of archaeological excavations in the Holy Land III: 89-97. Jerusalem: Israel Exploration Society.

Yekutieli, Y. 2006. The ceramics of Tel 'Erani, Layer C. Journal of the Serbian Archaeological Society 22: 225-42.

(C) The Author(s), 2021. Published by Cambridge University Press on behalf of Antiquity Publications Ltd. 